\title{
Possible intrusive food interaction with oral dabigatran's anticoagulant activity in a rat models
}

\author{
Naglaa Gamil Shehab ${ }^{1,2 \star}$, Rawoof Khan Gafoor Khan ${ }^{3}$, Eiman Shams Eldin \\ Elgailani ${ }^{4}$, Kholoud Yousuf Abu Shawish ${ }^{2}$ \\ ${ }^{1}$ Department of Pharmacognosy, Faculty of Pharmacy, Cairo University, Cairo, Egypt, ${ }^{2}$ Pharmaceutical Chemistry and Natural \\ Products Department, ${ }^{3}$ Pharmacology and Toxicology Department, ${ }^{4}$ Clinical Pharmacy and Pharmacy Practice Department, \\ Dubai Pharmacy College, Dubai, United Arab Emirates
}

*For correspondence: Email: naglaa@dpc.edu; Tel: 00971503212716

Sent for review: 29 June 2018

Revised accepted: 22 September 2018

\begin{abstract}
Purpose: To evaluate the synergistic or antagonistic interaction between oral dabigitran etexilate (Pradaxa) and some foods.

Methods: Aqueous extracts of sweet orange, cabbage, ginger, green tea, garlic and pineapple were prepared and lyophilized, and total phenolic acids and flavonoid contents evaluated. The residues of the aqueous extracts were given daily to the rats $(500 \mathrm{mg} / \mathrm{kg}$ dose, oral) $1 \mathrm{~h}$ after administration of dabigatran (1.83 $\mathrm{mg} / \mathrm{kg}$ dose) for 14 days. Bleeding time, International Normalized Ratio (INR), prothrombin time $(P T)$ as well as alanine aminotransferase (ALT), aspartate aminotransferase (AST) and alkaline phosphatase (ALP) in blood were measured.

Results: Oral administration of Pradaxa with all the test food (except cabbage) significantly increased bleeding time, INR and PT. Pradaxa interaction with cabbage significantly decreased bleeding tendencies but the drug did not produce any major elevation of liver enzyme levels (ALT, AST and $A L P)$. Conversely, significant elevation in ALP level was observed only after aqueous extract of ginger was administered with Pradaxa. Green tea and garlic significantly increased ALT and AST levels.

Conclusion: Synergistic interaction occurrs between dabigatran etexilate with the selected foods, but interaction with cabbage antagonistic.
\end{abstract}

Keywords: Dabigatran etexilate, Anticoagulant, Foods, Liver enzymes, International Normalized Ratio, Prothrombin time

\begin{abstract}
This is an Open Access article that uses a funding model which does not charge readers or their institutions for access and distributed under the terms of the Creative Commons Attribution License (http://creativecommons.org/licenses/by/4.0) and the Budapest Open Access Initiative (http://www.budapestopenaccessinitiative.org/read), which permit unrestricted use, distribution, and reproduction in any medium, provided the original work is properly credited.

Tropical Journal of Pharmaceutical Research is indexed by Science Citation Index (SciSearch), Scopus, International Pharmaceutical Abstract, Chemical Abstracts, Embase, Index Copernicus, EBSCO, African Index Medicus, JournalSeek, Journal Citation Reports/Science Edition, Directory of Open Access Journals (DOAJ), African Journal Online, Bioline International, Open-J-Gate and Pharmacy Abstracts
\end{abstract}

\section{INTRODUCTION}

Anticoagulant drugs are those drugs that decrease the danger of blood clots. Anticoagulants are used to treat atrial fibrillation and deep vein thrombosis. Dabigatran etexilate (Pradaxa) is a new oral anticoagulant drug with less side effects than other anticoagulant drugs (e.g., warfarin) [1]. Dabigatran is a direct thrombin inhibitors which inhibits free and clotbound thrombin and thrombin platelet aggregation. The drug is present in three strengths 75,110 and $150 \mathrm{mg}$, and it is always taken two times daily by the patient [2]. The 
structure of the drug is shown in Figure.<smiles>Cn1c(CNc2ccc(C(=N)N)cc2)nc2cc(C(=O)N(CCC(=O)O)c3ccccn3)ccc21</smiles>

Figure 1: Chemical structure of dabigatran

Herbal remedies have been used for centuries for their medical benefits. Some remedies have shown a significant role in treatment and prevention of some diseases, but they need to be used wisely when taken concomitantly with prescribed drugs to avoid serious adverse effects and interactions [3]. Due to limited food drug interaction studies, several phytochemical and pharmacological studies must be conducted to balance the level of therapeutic efficacy with the risk of toxicity [4]. Some herbs normally consumed as foods are known for their different coagulation effects either as anticoagulants or enhancing the coagulation time such as, garlic, ginger, green tea, pineapple, orange and cabbage [5]. Ginger has been reported to inhibit cyclooxygenase activity, platelet aggregation, and thromboxane synthetize activity [6]. In vitro studies of constituents of garlic revealed that garlic possesses antiplatelet effects [7]. The main constituent of green tea named catechin, has anti-platelet effect as it can prolong the bleeding time [8]. Furthermore, bromelain (the main constituent of pineapple) can increase the serum fibrinolysis ability, activated partial thromboplastin time (APTT) and prothrombin time (PT) [9]. In addition, orange fruit extract possess anti-platelet and anticoagulant effect by increasing activated partial thromboplastin time (APTT) and prothrombin time (PT) [10]. In contrast, cabbage and other green leaves such as cauliflower and spinach, contain vitamin $\mathrm{K}$ which is important for production of certain proteins in the liver (proteins $\mathrm{C}, \mathrm{S}$ and $\mathrm{Z}$ ) that is responsible for the clotting factors [11]. To evaluate the synergistic or antagonistic interaction between oral Dabigitran etexilate (Pradaxa) and some foods in correlation to their composition.

This study was aimed at evaluating the synergistic or antagonistic interactions between oral dabigitran etexilate (Pradaxa) and some foods in relation to their composition. Dabigitran etexilate had been approved by FDA as having lower bleeding risk than other oral anticoagulants [12].

\section{EXPERIMENTAL}

\section{Chemicals, drugs and apparatus}

Carboxymethylcellulose (CMC), assay kits for determination of, alanine aminotransferases $(\mathrm{ALT})$, aspartate aminotranferases (AST) and alkaline phosphatase (ALP) were obtained from Sigma Chemical Co. (St. Louis, MO, USA). Dabigatran etexilate 110 mg (Pradaxa ${ }^{\circledR}$, hard capsules Boehringer Ingelheim Pharma $\mathrm{GmbH}$ \& Co. KG, Biberach, Germany) was used in this study. The International normalized ratio (INR) and the Prothrombin Time (PT) were measured using Mission PT Coagulation Monitoring System Apparatus (Acon Laborateires, INC., San Diego, USA) .Total phenolic and flavonoid contents were measured by spectrophotometer (UV-1700, Pharma Spec, Shimadzu, Japan).

\section{Foods, materials and extraction}

Fresh sweet orange, cabbage, ginger, green tea, garlic and pineapple were purchased from the local vegetable market in Dubai, UAE (500 g each). All the selected foods were identified by Zayed Complex for Herbal Research and Traditional Medicine in Abu-Dhabi, UAE. The outer layers of oranges, ginger, pineapples and garlic were removed. The fresh plants were cut into small pieces. All plants under investigation except green tea, were separately mixed with distilled water using a blender while aqueous decoction of the green tea was prepared. The prepared aqueous extracts were filtered through gauze and then dried by lyophilization. The percentage yields of the dried extracts were determined and are presented in Table 1.

\section{Standardization of the aqueous extracts of foods}

The total contents of phenolic acids and flavonoids were evaluated colorimetrically using spectrophotometer. All experiments were performed in triplicate. Folin-Ciocalteu reagent was used to determine total phenolic content in alkaline medium [13,14]. Absorbance was measured at $750 \mathrm{~nm}$ against blank. Results were calculated as $\mathrm{mg} / \mathrm{g}$ gallic acid on dry weight of material. Total flavonoid content was evaluated by the aluminum chloride method. Quercetin was used as standard. The absorbance was measured at $510 \mathrm{~nm}$. The results are presented in Table 1.

\section{Experimental animals}

Healthy albino male rats weighing $200-220 \mathrm{~g}$ were obtained from the animal house of Dubai 
Pharmacy College. The animals were kept under standard hygienic conditions (relative humidity 50-60\%, temperature at $22 \pm 2{ }^{\circ} \mathrm{C}$, with $12 \mathrm{~h}$ day/night light cycle) and fed with a wellbalanced diet and water supplied ad libitum. The animals spent one week of accommodation before conducting the experiments. Ethical standards for the proper care and use of laboratory animals were applied to all biological investigations [15], and the work was approved by Research Unit and Ethical Committee of Dubai Pharmacy College, Dubai, United Arab Emirates (no. 12.10.16).

\section{In vivo anticoagulant studies}

The residues of the aqueous extracts of the six selected foods were separately suspended in 1 $\%$ CMC. The dose for each, was $500 \mathrm{mg} / \mathrm{kg}$. The animals were randomly distributed to eight groups ( $n=6)$ : group I (Control), received $1 \%$ of CMC; group II, administrated Dabigatran etexilate in a dose of $1.83 \mathrm{mg} / \mathrm{kg}$; groups III - VIII: administrated dabigatran etexilate in a dose of $1.83 \mathrm{mg} / \mathrm{kg}$ and then after one hour they received the selected foods separately in a dose of 500 $\mathrm{mg} / \mathrm{kg}$ suspended in $1 \%$ CMC. All the previous groups were daily received the doses orally.

After 14 days of administration, blood samples were collected from the retro-orbital vein. International Normalized Ratio (INR) and Prothrombin Time (PT) were analyzed using Mission PT Coagulation Monitoring System apparatus.

\section{Bleeding model}

A rat-tail incision bleeding model, as described by Gustafsson et al [16] was used. All animals were fasted overnight, and then received a single oral dose of Dabigatran etexilate alone (1.83 $\mathrm{mg} / \mathrm{kg}$ ) or dabigatran etexilate with the selected foods $(500 \mathrm{mg} / \mathrm{kg}$ ) via gastric gavage. Bleeding time was measured using a spring-loaded blade device (Surgicutt®; Loxo, Dossenheim, Germany). The device was applied on the surface of the tail to make incision. Blood flow was blotted using filter paper which held directly below the tail. Every $30 \mathrm{sec}$, the position of the filter paper was changed until no longer development of a red crescent (end of bleeding).

\section{Assay of liver enzymes}

Samples of the blood were obtained from the orbital sinus of each rat. Plasma was separated by centrifugation at $3500 \mathrm{rpm}$ and was used for the liver enzymes analyses (aspartate aminotransferase (AST), alanine aminotransferase (ALT) and alkaline phosphatase (ALP)).

\section{Statistical analysis}

One-way ANOVA followed by post hoc analysis were used to analyze the data with the aid of. SPSS software, version 25. The data are expressed as mean \pm standard deviation (SD, $\mathrm{n}$ $=3) . P<0.05$ and $<0.01$ were considered statistically significant.

\section{RESULTS}

\section{Composition of aqueous food extracts}

The part used and the percentage yield of each food extract are represented in Table 1. Evaluation of the total phenolic content of the selected foods aqueous extracts revealed that highest percentage yield was observed in green tea followed by pineapple (19.0, and $7.8 \%$ respectively) calculated as gallic acid equivalents. On the other hand, highest flavonoid contents percentages were observed in green tea, garlic and sweet orange (40, 30, and $25 \%$ respectively) expressed as grams of quercetin per 100 grams of dry plant material.

\section{In vivo anticoagulant effects}

Oral administration of all tested foods (except cabbage) with Pradaxa significantly increased the bleeding time, INR and PT. On the other hand, oral administration of Pradaxa with cabbage significantly decreased the bleeding time as shown in Table 2.

\section{Liver enzymes}

No significant elevation on the ALT, AST and ALP was observed after treating the animals once daily with Pradaxa for two weeks, as shown in Table 2. On the other hand, significant elevation in ALP level was observed by ginger residue. Moreover, oral administration of green tea and garlic separately with Pradaxa significantly increased ALT and AST levels as shown in Table 2. In contrast, oral administration of Pradaxa with cabbage significantly decreased the level of ALT.

\section{DISCUSSION}

Dabigatran etexilate or Pradaxa is a new oral anticoagulant drug and the most extensively used for treating pulmonary embolism and deep vein thrombosis with little side effects. Few reports are available about food-Dabigatran interaction [2,17]. Dabigatran (direct thrombin 
Table 1: Yield and total phenolic and flavonoid contents of selected foods

\begin{tabular}{|c|c|c|c|c|c|}
\hline Common name & Latin name & Fruit part & Yield (\%) & $\begin{array}{c}\text { Total } \\
\text { phenolics } \\
(\%)\end{array}$ & $\begin{array}{c}\text { Total } \\
\text { flavonoids (\%) }\end{array}$ \\
\hline Sweet orange & $\begin{array}{l}\text { Citrus sinensis F. } \\
\text { Rutaceae }\end{array}$ & Fruit & 48.4 & 1.5 & 25 \\
\hline Cabbage & $\begin{array}{l}\text { Brassica oleracea F. } \\
\text { Brassicaceae }\end{array}$ & Leaf & 50.6 & 3.7 & 20 \\
\hline Ginger & $\begin{array}{l}\text { Zingiber officinale F. } \\
\text { zingiberacea }\end{array}$ & Rhizome & 32.3 & 6.0 & 14 \\
\hline Green tea & $\begin{array}{l}\text { Camellia sinensis } \mathrm{F} \text {. } \\
\text { Theaceae. }\end{array}$ & Lear & 68.5 & 19.0 & 40 \\
\hline Garlic & $\begin{array}{l}\text { Allium sativum } \\
\text { F. Liliaceae }\end{array}$ & Bulb & 40.1 & 1.0 & 30.0 \\
\hline Pineapple & $\begin{array}{l}\text { Ananas comosus F. } \\
\text { Bromeliaceae }\end{array}$ & Fruit & 60.0 & 7.8 & 15 \\
\hline
\end{tabular}

Table 2: Effect of some food extracts on the anticoagulant activity of oral dabigatran (Pradaxa) in a rat model

\begin{tabular}{|c|c|c|c|c|c|c|c|}
\hline $\begin{array}{l}\text { Animal } \\
\text { group }\end{array}$ & Group $^{a}$ & $\mathrm{BT}^{\mathrm{b}}$ & INR & PT & AST & ALT & ALP \\
\hline I & Control & $7.0 \pm 1.41$ & $1.15 \pm 0.07^{*}$ & $14.20 \pm 0.14^{\star \star}$ & $89.90 \pm 1.55$ & $39.15 \pm 1.62$ & $175.10 \pm 7.21$ \\
\hline II & Pradaxa only & $26.0 \pm 1.41^{*}$ & $2.75 \pm 0.07^{* \star}$ & $37.35 \pm 1.77^{* *}$ & $91.00 \pm 1.41$ & $38.70 \pm 0.42$ & $172.65 \pm 3.32$ \\
\hline III & $\begin{array}{l}\text { Pradaxa }+ \\
\text { orange }\end{array}$ & $60.0 \pm 7.07^{\star \star}$ & $6.60 \pm 0.84^{\star \star}$ & $83.00 \pm 3.95^{\star *}$ & $90.80 \pm 0.98$ & $41.75 \pm 1.76$ & $205.35 \pm 6.85$ \\
\hline IV & $\begin{array}{l}\text { Pradaxa + } \\
\text { ginger }\end{array}$ & $86.5 \pm 6.36^{\star \star}$ & $6.75 \pm 0.35^{\star \star}$ & $97.80 \pm 3.25^{\star \star}$ & $101.40 \pm 1.27$ & $33.25 \pm 3.18$ & $327.55 \pm 3.74^{*}$ \\
\hline V & $\begin{array}{l}\text { Pradaxa + } \\
\text { pineapple }\end{array}$ & $84.75 \pm 6.71^{\star *}$ & $6.65 \pm 0.21^{* *}$ & $90.82 \pm 3.00^{* *}$ & $89.15 \pm 1.20$ & $36.75 \pm 1.06$ & $174.90 \pm 1.27$ \\
\hline VI & $\begin{array}{l}\text { Pradaxa + } \\
\text { garlic }\end{array}$ & $28.65 \pm 1.90^{*}$ & $4.70 \pm 0.42^{\star \star}$ & $70.85 \pm 0.91^{* *}$ & $287.00 \pm 4.24^{\star *}$ & $193.85 \pm 1.9^{\star *}$ & $169.40 \pm 1.27$ \\
\hline VII & $\begin{array}{l}\text { Pradaxa + } \\
\text { cabbage }\end{array}$ & $4.25 \pm 0.35^{\star}$ & $0.65 \pm 0.07$ & $9.75 \pm 0.36$ & $99.50 \pm 5.65$ & $11.50 \pm 1.41^{\star *}$ & $78.50 \pm 89.51$ \\
\hline VIII & $\begin{array}{l}\text { Pradaxa }+ \\
\text { green tea }\end{array}$ & $37.25 \pm 3.18^{*}$ & $5.40 \pm 0.14^{\star \star}$ & $76.57 \pm 2.93^{* *}$ & $230.65 \pm 41.93^{\star *}$ & $205.80 \pm 6.78^{\star \star}$ & $262.95 \pm 4.03$ \\
\hline
\end{tabular}

${ }^{a}$, all the selected food extracts were separately orally administered just after one hour of the administration of Pradaxa; ${ }^{b}$ In minutes ; *significant difference $(p<0.05)$ compared to control group; ${ }^{* *}$ significant difference $(p<$ $0.01)$ compared to control group

inhibitor) has a rapid onset of action, a short plasma half-life, a predictable pharmacokinetic profile and it does not need any regular blood tests to see the blood-thinning level. No dietary restrictions were previously reported [18].

INR provides information about the blood tendency to clot (thin or thick) while the prothrombin time (PT) is the time for the blood to clot [19]. Dose selection for cabbage, pineapple, ginger, green tea, orange, garlic and Pradaxa was based on published data as well as the average body weight of the human (70 kg) [20]. A dose of $500 \mathrm{mg} / \mathrm{kg} \mathrm{b.wt} \mathrm{in} \mathrm{rats} \mathrm{was} \mathrm{used} \mathrm{for}$ the selected foods which equivalent to $35 \mathrm{~g}$ in human being (average body weight, $70 \mathrm{~kg}$ ). This study proved that oral administration of all tested foods except cabbage after one hour of Pradaxa administration, significantly amplified the bleeding time and significantly increased both INR and PT. Higher INR and PT can propose bleeding tendencies and increase the risk of the bleeding when those selected foods are taken with Pradaxa. On the other hand, oral administration of Pradaxa with cabbage can decrease the bleeding tendencies and can promote the time of clotting. This clotting effect is due to the presence of vitamin $\mathrm{K}$ in cabbage, vitamin $\mathrm{K}$ is an important factor for producing a protein in liver which responsible for the clotting factors [21].

No significant elevation on ALT, AST and ALP was observed after treating the animals once daily with Pradaxa for two weeks as shown in Table 2 which confirmed that Pradaxa did not have hepatotoxicity on short treatment (two weeks only) [22]. In contrast, significant elevation in ALP level was noticed by oral administration of the aqueous extract of ginger with Pradaxa. As a result of high ALP level, the cholestasis may occur [23]. Oral administration of green tea with Pradaxa significantly increased ALT and AST levels. United States Pharmacopeia shows evidence for the green tea extract that causes hepatotoxicity which noticed by elevation of the levels of liver enzymes in blood [24]. Preclinical 
and human study proved that the epigallocatechin-3-gallate, a component of green tea, can induce mitochondrial toxicity and generate the reactive oxygen species, although green tea showed the highest antioxidant effect [25]. Similarly, elevation of liver enzymes especially ALT and AST was observed after oral administration of Pradaxa with garlic (192.5, $284.0 \mathrm{IU} / \mathrm{L}$ respectively). It was proved that, oral administration of the fresh garlic in high dose up to $1 \mathrm{~g} / \mathrm{kg}$ to the rats showed significant deterioration in liver enzymes [26]. In contrast, administration of cabbage with pradaxa significantly decreases the level of ALT (11.50 IU/L).

\section{CONCLUSION}

The findings of the present study indicate that some food/dabigatran interactions occur in rats and thus, may also occur in human beings. Further studies are, however, required to ascertain the nature of these interactions. Health care professionals who prescribe and dispense dabigatran etexilate are advised to counsel patients to avoid drinking or eating these selected foods with and/or shortly before/after the administration of the drug.

\section{DECLARATIONS}

\section{Acknowledgement}

The authors thank Professor Saeed A. Khan, Dubai Pharmacy College Dean, for his continuous support in this research and Ms. Aisha Morsy, Ms Eman Fawzi, Ms Shefaa Maraka and Ms Hafsa Samy for being helpful in this work.

\section{Conflict of Interest}

No conflict of interest associated with this work.

\section{Contribution of Authors}

The authors declare that this work was done by the authors named in this article and all liabilities pertaining to claims relating to the content of this article will be borne by them. Naglaa G Shehab conceived and designed the study, Naglaa G Shehab, Rawoof Kh G Khan, Eiman Sh E Elgailani and Kholoud $Y$ Abu Shawish collected and analysed the data. All the authors wrote the manuscript, read and approved the manuscript for publication.

\section{REFERENCES}

1. Ciurus T. Dabigatran: Review of Pharmacology and Management of Bleeding Complications of This Novel Oral Anticoagulant J Med Toxicol 2011; 7: 281-287.

2. Fanola CL. Current and emerging strategies in the management of venous thromboembolism: benefit-risk assessment of dabigatran Vasc Health Risk Manag 2015; 11: 271-282.

3. Martins E. The growing use of herbal medicines: issues relating to adverse reactions and challenges in monitoring safety Front Pharmacol 2013; 4: 177.

4. Tres JC. Interaction between medicines and medicinal plants An Sist Sanit Navar 2006; 29: 233-252.

5. Samuels $N$. Herbal remedies and anticoagulant therapy Thromb Haemost 2005; 93: 3-7.

6. Tsai HH, Lin HW, Lu YH, Chen YL, Mahady GB. A Review of Potential Harmful Interactions between Anticoagulant/Antiplatelet Agents and Chinese Herbal Medicines PLOS ONE 2013; 8: 5.

7. Abdul MI, Jiang $X$, Williams KM, Day RO, Roufogalis $B D$, Liauw WS, Xu H, McLachlan AJ. Pharmacodynamic interaction of warfarin with cranberry but not with garlic in healthy subjects Br J Pharmacol 2008; 154: 1691.

8. Kang WS, Lim IH, Yuk DY, Chung KH, Park JB, Yoo HS, Yun YP. Antithrombotic Activities of Green Tea Catechins and (-)-Epigallocatechin Gallate Thromb Res 1999; 96: 229-237.

9. Pavan R, Jain S, Shraddha, Kumar A. Properties and Therapeutic Application of Bromelain: A Review. Biotechnol Res Int 2012; 2012: 1-6.

10. Mallick N, Khan RA. Effect of Citrus sinensis (sweet orange) on coagulation South Asian J Exp Biol 2014; 4: 54-60.

11. Müller F, Gailani D, Renné, T. Factor XI and XII as antithrombotic targets Curr Opin Hematol 2011; 18: 349-355.

12. Eikelboom J, Merli G. Bleeding with Direct Oral Anticoagulants vs Warfarin: Clinical Experience Am J Med 2016; 129: S33-S40.

13. Oktay M, Gülçin I, Küfrevioğlu Öi. Determination of in vitro antioxidant activity of fennel (Foeniculum vulgare) seed extracts Lebensm Wiss U Technol 2003; 36: 263271.

14. Olszewska MA. In vitro antioxidant activity and total phenolic content of the inflorescences, leaves and fruits of Sorbus torminalis (L.) Crantz Acta Pol Pharm 2012; 69(1):167

15. Committee for the Update of the Guide for the Care and Use of Laboratory Animals, Guide for the care and use of laboratory animals 2010; 8th edition, National Academic press, Washington.

16. Gustafsson D, Elg M, Lenfors S, Börjesson I. \& TegerNilsson A. C. Effects of inogatran, a new low-molecularweight thrombin inhibitor, in rat models of venous and arterial thrombosis, thrombolysis and bleeding time Blood Coagul Fibrinolysis Int J Haemost Thromb1996; 7: 69-79.

Trop J Pharm Res, October 2018; 17(10):2035 
17. Heidbuchel $H$, Verhamme $P$, Alings $M$, Antz M, Hacke W, Oldgren J, Sinnaeve P, Camm AJ, Kirchhof P, European Heart Rhythm Association. European Heart Rhythm Association Practical Guide on the use of new oral anticoagulants in patients with non-valvular atrial fibrillation Europace 2013; 15: 625-51.

18. Ciurus T, Sobczak S, Cichocka Radwan A, Lelonek M. New oral anticoagulants - a practical guide Kardiochir Torakochirurgia Pol 2015; 12(2): 111-8.

19. lijima $S$, Baba $T$, Ueno $D$, Ohish $A$. International normalized ratio testing with point-of-care coagulometer in healthy term neonates BMC Pediatr 2014; 14: 179.

20. Wienen W, Stassen JM, Priepke H, Ries UJ, Hauel N. Effects of the direct thrombin inhibitor dabigatran and its orally active prodrug, dabigatran etexilate, on thrombus formation and bleeding time in rats Thromb Haemost 2007;98(2):333-8.

21. Kim ES, Kim MS, Na WR \& Sohn CM. Estimation of vitamin $K$ intake in Koreans and determination of the primary vitamin K-containing foods sources based on the fifth Korean National Health and Nutrition
Examination Survey (2010-2011) Nutr Res Pract 2013; 7: 503-9.

22. Lee WM, Larrey D, Olsson R, Lewis JH, Keisu M, Auclert $L$, Sheth S. Hepatic findings in long-term clinical trials of ximelagatran Drug Saf 2005; 28(4): 351-70.

23. Giannini EG, Testa R, Savarino V. Liver enzyme alteration: a guide for clinicians CMAJ 2005; 172(3): 367-79.

24. Sarma $D N$, Barrett $M L$, Chavez ML, Gardiner $P, K o R$, Mahady GB, Marles RJ, Pellicore LS, Giancaspro GI, Low Dog T. Safety of green tea extracts: a systematic review by the US Pharmacopeia Drug Saf 2008; 31(6): 469-84.

25. James KD, Kennett MJ, Lambert JD. Potential role of the mitochondria as a target for the hepatotoxic effects of ()-epigallocatechin-3-gallate in mice Foods Chem Toxicol 2018; 111: 302-309.

26. Rana SV, Pal R, Vaiphei K, Singh K. Garlic hepatotoxicity: safe dose of garlic Trop Gastroenterol 2006; 27(1): 26-30. 